\title{
INTERPRETATION AND RECTIFICATION IN AUSTRALIA
}

Both interpretation and rectification continue to pose problems. Difficulties are compounded by blurring the boundary between the two. In Simic v New South Wales Land and Housing Corporation [2016] HCA 47 the High Court of Australia overturned the decisions of the lower courts which had held that performance bonds could be interpreted in a "loose" manner in order to correct a mistake. However, the documents could be rectified in order to reflect the actual intentions of the parties. This decision should be welcomed: the mistake was more appropriately corrected through the equitable jurisdiction than at common law. Significantly, the concurring judgments of French C.J. and Kiefel J. highlight that the law of rectification now seems to be different in Australia than in England. It is to be hoped that the English approach will soon be revisited (see further P. Davies, "Rectification versus Interpretation" [2016] C.L.J. 62).

Nebax Constructions Australia Pty Ltd ("Nebax") entered into a contract with the New South Wales Land and Housing Corporation ("the Corporation") for the demolition and construction of certain buildings. Under the contract, Nebax was obliged to obtain from the Australian and New Zealand Banking Group Ltd ("ANZ") two unconditional performance bonds in favour of the Corporation. This would entitle the Corporation to require ANZ to pay it a total of \$146,965.06 upon a written demand. Unfortunately, Mr Simic, a director of Nebax, gave to Ms Hanna, an employee of ANZ, the wrong details. Instead of the favouree of the bonds being "New South Wales Land and Housing Corporation, with the Australian Business Number ("ABN") 24960729 253", which corresponded to the Corporation, the bond was in favour of "New South Wales Land \& Housing Department trading as Housing NSW ABN 45754121 940 ". That was a mistake. In fact, there was not, and has never been, any government department called the "New South Wales Land \& Housing Department", and the ABN was also clearly incorrect.

Three years after the contract had been entered into, the Corporation sought payment under each bond from ANZ. The Bank refused to pay, since the Corporation was not the named favouree. The first question was whether the bonds should be interpreted such that "New South Wales Land \& Housing Department trading as Housing NSW ABN 45754121 940" could be read as 
meaning "New South Wales Land and Housing Corporation, with the ABN 24 960729 253". This would appear to alter the words chosen by the parties. Nevertheless, this was acceptable to both Kunc J. at first instance and the New South Wales Court of Appeal, which emphasised the context surrounding the performance bonds: their purpose was to fulfil the underlying contractual obligations of Nebax towards the Corporation, and favouree of the bonds should be understood to be the same as the counterparty to the underlying contract - in other words, the Corporation.

The High Court firmly rejected such a "loose approach to construction" (at [11] per French C.J.). As French C.J. clearly explained in his concurrence, two complementary principles apply to performance bonds: the principle of strict compliance and the principle of autonomy. The latter demands that the performance bond be interpreted independently, and should not be qualified by reference to the terms of the underlying contract: the bank should be able to rely upon the language of the bond alone, without investigating the underlying the contract. Further burdens should not be placed on banks which issue performance bonds. The former principle requires the bond to be interpreted strictly, such that the bank only has an obligation to pay - and can only claim an indemnity for its performance - if the conditions on which the bank is authorised and compelled to make payment are strictly observed. This is important. The joint judgment of Gageler, Nettle and Gordon JJ. explains that a bank is contractually bound to adhere to the terms of a bond; by paying a party not named on the face of the instrument the bank may be exposed to claims for breach of contract. It is therefore understandable why ANZ did not pay the Corporation on demand.

The significance of context and the "factual matrix" within which an agreement is concluded is a controversial subject. The lower courts in Simic considered the relevant background material to include the underlying agreement, and felt able to interpret a term of the contract other than in accordance with its plain meaning. The High Court sensibly refused to endorse such a liberal approach towards interpretation. The nature and function of performance bonds demands a strict approach towards interpretation. It is suggested that a strict approach should also be favoured more generally, and that English law appears to be moving in this direction too (see e.g. Arnold $v$ Britton [2015] UKSC 36; [2015] A.C. 1619; Lord Sumption, "A Question of Taste: The Supreme Court and the Interpretation of Contracts" (Harris Society Annual Lecture, 8 May 2017) https://www.supremecourt.uk/docs/speech170508.pdf). Minor "typos" may be corrected in the interpretative exercise, but 
substantial mistakes - such as that made in Simic - are best corrected via the equitable remedy of rectification.

In Simic, the performance bonds were agreed between Nabax and ANZ in favour of the Corporation. When deciding whether to rectify the bonds, the High Court rightly focussed on the intentions of Nabax (through Mr Simic) and ANZ (through Ms Hanna). Mr Simic was clearly mistaken, since he intended the favouree of the bonds to be the Corporation. It seems appropriate to conclude that Ms Hanna had a similar intention that the bonds reflected what was required under the underlying contract. After all, if someone had pointed out to Mr Simic and Ms Hanna that the name of the counterparty was wrong straight away, then both parties would surely have agreed immediately. It follows that the performance bonds did not reflect the parties' actual intentions due to a common mistake, and rectification was granted.

In rectifying the performance bonds, the High Court applied the traditional test for rectification on the basis of common mistake. The written instrument was made to conform to the true agreement of the parties, and that agreement does not need to be specifically enforceable. Interestingly, both French C.J. and Kiefel J. in their separate concurring judgments commented on the different approach towards rectification developing in England. In Chartbrook Ltd. v Persimmon Homes Ltd. [2009] UKHL 38; [2009] 1 A.C. 1101 Lord Hoffmann, obiter, suggested (at [59]-[60]) that "the terms of the contract to which the subsequent instrument must conform must be objectively determined in the same way as any other contract", and that "the question is what an objective observer would have thought the intentions of the parties to be". As the concurring judgments illustrate, this is a departure from traditional equitable principle which concentrates on the parties' actual intentions. It is difficult to see why an earlier objective accord should trump a later, formal agreement unless the written instrument fails to reflect the parties' actual intentions. Moreover, Lord Hoffmann's approach surprisingly allows a court to find a common mistake because a reasonable person would consider that one party was mistaken, even if one party was not actually mistaken at all (cf. Chartbrook Ltd. v Persimmon Homes Ltd. [2007] EWHC 409 (Ch); [2007] 1 All E.R. (Comm) 1083 at [138]-[164] (Briggs J.)).

The approach in Simic reflects the traditional approach to rectification; both French C.J. and Kiefel J. were clear that the views of Lord Hoffmann in Chartbrook involve a departure from that approach. Both Justices said that Australia should not follow this aspect of Chartbrook without full argument in a case where the issue was relevant to the outcome. This is sensible, and it is 
suggested that Lord Hoffmann's approach should not be endorsed in any event. Indeed, even in England Lord Hoffmann's approach has given rise to much controversy, and a number of judges have been moved to express strong views in extra-judicial speeches and articles (for a sample, see Davies [2016] C.L.J. 62 , fn. 6). It is to be hoped that this issue will be considered fully by an appellate court in this jurisdiction as well. In Chartbrook, Lord Hoffmann's views on rectification were obiter, and in Daventry District Council v Daventry \& District Housing Ltd. [2011] EWCA Civ 1153; [2012] 1 W.L.R. 1333 Lord Hoffmann's approach regarding rectification was not contested. This is problematic. As French C.J. rightly observed (at [18]), "[a]t a conceptual level, construction and rectification of a contract are different processes".

PAUL S. DAVIES

Faculty of Laws, University College London 